\title{
Multinational Federalism and Fiscal Autonomy
}

\section{François Boucher}

\section{Introduction}

In the last decades, sub-state nationalist movements in Western countries have often struggled to obtain more fiscal autonomy, that is, more power to tax their citizens and to spend on public programs as they see fit. This topic was central in the Scottish referendum on independence of 2014 (Scottish Government 2013, 2014; McEwen and Pertersohn 2015). Quebec's nationalists have criticized the Canadian federal government for abusing its power to tax citizens and spend in areas of competence reserved to the provinces (Gagnon and Iacovino 2007, Noël 2009). Catalan nationalists have been worried about implicit transfers to other autonomous communities resulting from the Spanish State taxation system and fiscal autonomy (Balcells, Fernández-Albertos and Kuo 2015; Sanjaume 2018). However, very few works in normative political theory address the issue of fiscal decentralization in plurinational federations. ${ }^{1}$ There seems to be a presumption, especially among liberal egalitarian philosophers, that the welfare state must be a unitary state. Even the proponents of multinational federalism as a device to accommodate minority nationalism have tended to limit the self-government rights of minority nations to cultural matters (language, national symbols, education, immigration), implicitly leaving taxation and social policy as competences reserved to central governments.

Such a presumption is not surprising. In general, liberals tend to be suspicious of decentralization and local autonomy for sub-state groups, whether they are religious organizations, national minorities, regions, universities or cities. As Jacob Levy explains, autonomy for intermediary or sub-state groups and associations generates power and power tends to generate oppression. Hence, liberals have been worried that by freeing sub-state groups from the homogenizing pressures of central states and cultural majorities, group autonomy exacerbates another form of oppression, the oppression of individuals from within their group of belonging (2015). Many liberals thus maintain that in order to avoid exacerbating this form of oppression of minorities within minorities, central states need to retain the power to interfere within group life and enforce liberal norms. Even those who are sensitive to the threat that majorities and central states can pose to freedom and individuality tend to view this threat as being less important than the one that group life poses to individual freedom. For instance, Mill famously claimed that: "any despotism is preferable to local despotism. If we are to be ridden over by authority, if our affairs are to be managed for us at the pleasure of other people, heaven forefend that it should be at that of our nearest neighbours" (Mill 1977, 606).

In his works on federalism, Levy has tried to rehabilitate a strand of liberal thought that is favorable to group autonomy and decentralization $(2007 ; 2015)$. He makes the case that liberalism should be disentangled from the assumption that centralization and the indivisibility of state sovereignty are always necessarily better than decentralization and local autonomy. The relation between liberalism's fundamental principles and centralization / decentralization is a contingent one. In certain societal contexts, at certain points in history, freedom is better served by centralization. At other places and times, it is better protected by decentralization and group autonomy.

Of course, contemporary liberals are not only concerned with the promotion of individual autonomy. Most notably, egalitarian liberals, since the publication of Rawls's A Theory of Justice

${ }^{1}$ There are of course some notable exceptions: Follesdal, 2001, Van Parijs 2004, 2015, Segall, 2007, Boucher and Maclure, 2015; Shorten 2015. 
(1971), have been busy arguing about the merits of different conceptions of egalitarian distributive justice. In his early works, Rawls simply assumes that his conception of justice applies within a unitary state that does not contain various tiers of government and various national groups. This assumption is reflected in the many works on distributive justice that came after Rawls theory of justice as fairness. As we know, theories of distributive justice were brought beyond the context of a unitary state to address issues of global justice. Nonetheless, those theories are made to apply to the context of international relations between sovereign unitary states that are not incorporated into a larger world government, even those that claim that there is a global basic institutional structure and start from a cosmopolitan framework taking individuals to be the fundamental units of moral concerns. ${ }^{2}$

In this chapter, I want to challenge the assumption that redistribution must occur within a unitary state by situating discussions of distributive justice in the context of decentralized federal states. More precisely, I want to look at the shape that the welfare state should take in plurinational federations. How should redistribution be organized in states that adopt a federal structure so as accommodate sub-state national minorities by granting them a meaningful degree of autonomy and recognition? By doing this, I want to accomplish something akin to Levy's project of disentangling liberty and centralization. I want to sketch the contours of a conception of multinational federalism that disentangles redistribution and social policy from fiscal centralization. I will lay the foundations of an egalitarian conception of fiscal federalism by arguing that in plurinational states, fiscal decentralization, that is, the sharing of taxation and spending powers between different orders of governments, is entailed by the equal recognition of minority nations and that it does not necessarily undermine socio-economic equality. In the first section, I explain that the topic of nationalism as largely been understood by scholars as a phenomenon related to identity and culture and disconnected from social policy and redistribution. In the second section, I explain that in normative political theory, scholars have mostly understood the institutional forms giving recognition to minority nations in terms of cultural autonomy. In the third section, I explain why recognition and cultural autonomy for minority nations entails fiscal autonomy. In the fourth section, I answer certain egalitarian concerns with fiscal decentralization within plurinational federations.

\section{Nationalism and Social Justice}

Scholars of nationalism often focus on the identity component of nationalism or national identity, paying less attention to the economic dimensions. For instance, sociologists and political scientists have mostly explained how the modern world has come to be divided in nations, appealing in doing so to cultural, ethnic, political and psychological factors. In general, their theories of nationalism have followed three different paths. First, theories of primordialism and perennialism argue that nations have their origins in ethnocultural groups that predate modernity and industrialization; their roots lie in human tendencies to bound with kin groups defined in terms of common ancestry or of the sharing of objective cultural traits such as language and religion or in the persistence of non-rational psychological bounds within perceived kin groups (van den Berghe 1981; Geertz 1973; Horowitz, 1985, Connor 1994). Second, modernist and constructivist theorists claim that nations only really emerged approximately in the late $18^{\text {th }}$ century and were purely a product of modernity and

\footnotetext{
${ }^{2}$ Notable exceptions to this include Cabrera's (2004) and certain theoreticians of multiscalar and cosmopolitan democracy (Archibugi 2008, Held 1995).
} 
industrialization. National identities, in their views, were crafted by elites who engaged in processes of nation-building and who thereby diffused their "high culture" or were created less deliberately as the byproducts of the structural necessities linked to the integration to the labour market in industrial societies (which was possible by the dissemination of standardized national languages through education) or of the spreading of a national consciousness through the establishment of national written presses targeting mass audiences (Gellner 1983, Anderson 1983, Hobsbawn 1990). Finally, for the proponents of ethnosymbolism, nations are indeed social and political constructions, but those constructions still draw largely on the myth and symbols associated with shared ethnicity and kinship (Smith 1986).

Political philosophers who addressed nationalism have been more concerned with conceptual and normative questions than with explaining the historical origins of nations and nationalism. On the one hand, those political philosophers tried to formulate a concept of the nation, a definition of what a nation is. Their definitions capture the cultural dimension of nationalism. For instance, David Miller claims that nations have five essential components: first, nations are constituted by the shared belief of their members of forming a distinct community; second they are historical community; third, they have a collective agency and are bound by a desire to do things collectively and to make collective decisions; fourth they have a defined territory; and fifth, they have a distinct character, a common public culture (Miller 1995, 22-25). Kymlicka, provides a similar definition of the nation as a "historical community, more or less institutionally complete, occupying a given territory or homeland, sharing a distinct language and culture" (Kymlicka 1995, 11).

On the other hand, philosophers have also debated the desirable forms of national identity and national attachment; they have argued about the forms of nationalism conductive to human flourishing and about the effect of denying some citizens equal respect and full inclusion. Certain philosophers and political thinkers have promoted deep and thick forms of attachment to the ethnic or cultural nation, where shared ancestry or a shared way of life forms the basis of nationhood. The most prominent representative of such cultural nationalism is without any doubt the romantic German philosopher Johann Gottfried Herder (see Schmidt 1956; Wilson 1973). In contrast, proponents of purely civic nationalism maintain that national identities, in order to be inclusive and compatible with individual liberty and equal respect, should be purely based on political symbols and values and on loyalty to a constitution (Habermas 1998, Baritteau 1998). Between those two extremes, several philosophers have proposed ways to understand national identity without embracing the exclusive features of ethnic nationalism while offering a vision of the nation more rooted into history and into cultural particularity than the purely civic variant (Laborde 2001, 2002, Seymour 1999). Those normative debates mostly attend to the identity dimension of nations and nationalisms and do not attempt to link national identities to redistributive politics.

It would nonetheless be mistaken to assert that normative political theory has not addressed the topic of nationalism in relation to questions of social justice and redistribution. Indeed, political philosophers have long noted that the most influential theory of social justice, John Rawls's theory of justice as fairness (1971), confines the application of the principle of distributive justice within the boundary of a single society conceived as a "closed scheme of social cooperation", that is, to what Rawls calls the "basic structure of society". Although in its initial formulation in A Theory of Justice (1971) Rawls does not explicitly say that a closed scheme of social cooperation is equivalent to a nation, his later work The Law of Peoples (1999) makes it clear that social justice applies within distinct 
peoples conceived as groups of individuals sharing common sympathies and an awareness of their history and cultural accomplishment, ruled by a common government and attached to a common conception of justice and to a desire of protecting their independence and territorial integrity. This assumption has been the focus of intense debates. On one hand, cosmopolitan theorists of social justice have claimed that obligations of justice are also owed to foreigners and that global inequalities are morally arbitrary and unacceptable (for instance, Singer 1971, Beitz 1979; Caney 2005; Brock 2009; Gilabert 2012). On the other hand, liberal nationalists have been critical of global egalitarianism and have maintained that it is legitimate to be partial towards our co-nationals and that schemes of egalitarian redistribution should operate within nations (Miller 2008). Those nationalists and statists claimed that nation-states are communities of obligations setting the boundaries of schemes of redistribution and that a shared national identity provides the motivational resources that individuals need in order to accept to make sacrifices in the name of redistribution to fellow human beings with whom they have no face-to-face contact (Miller 1995, Tamir 1993, Moore 2001, for a nuanced and critical approach to the liberal nationalist thesis, see Banting and Kymlicka 2017). Similarly, statist conceptions of the boundaries of social solidarity have claimed that redistribution should only occur among those who are commonly subjected to state coercion (Blake 2001, Heath 2005, Nagel 2005).

Yet, the impressively large literature on the tensions between cosmopolitan social justice and national partiality does not explicitly address the questions of redistribution and fiscal decentralization within plurinational states. It is not clear that we can reach conclusions about social justice within such plurinational polities from those reached in debates about the justice and redistribution in the international sphere. The reason is that plurinational states are significantly distinct from the international order so that the question of redistribution at the scale of a world of independent nationalstates is not the same as the question of redistribution within a state comprising several nations. To start with, although there are emerging patterns of global governance in international relations (Roseneau and Czempiel 1992; Held and McGrew 2002) as well as practices of soft international law coexisting with a very limited sphere of hard international law (with the International Criminal Court, for instance), there is no global sovereign, no final legal and political authority at the international level (Nagel 2005, Heath 2005). By contrast, although plurinational states are often decentralized or have a multilayered and federal structure of "shared-rule and self-rule" (Watts 1999), they are nonetheless sovereign states in which the central government has the effective capacity to enforce laws on its territory. Moreover, although plurinational states are "deeply divided" (Taylor 1991) in the sense that they contain more than one people seeking to obtain or maintain significant collective selfgovernance, their citizens nonetheless usually display a certain level of attachment to the central state or to the broader plurinational society. Whereas the international sphere is fragmented into fully separate peoples or communities since there is no overarching cosmopolitan political identity, citizens of plurinational states are simultaneously the members of two national groups (De Schutter 2011), they have dual or "nested identities" (Miller 1998) or "separate loyalties" (Levy 2007). They belong to two overlapping identity groups. Much in the same vein, one can say that whereas there is no global demos, no global political community; the citizens of plurinational polities partake to the public life of two overlapping political communities (provincial and federal, for instance), they vote and deliberate at two levels and are included into two demoi. Plurinational states, especially those who adopt a federal structure, are neither similar to unitary states nor to the international sphere, they represent an "inbetween" (De Schutter 2011) which calls for a separate treatment. 


\section{Equal Recognition and Cultural Autonomy in Plurinational States}

Normative debates on distributive justice and nationalism have largely ignored issues of redistribution within plurinational polities. However, we can also assert that debates on the accommodation of plurinational diversity within a single state have adopted a "culturalist" outlook and have, to a large extent, been more focused on the political dimensions of self-government and group recognition than on fiscal decentralization and intergroup redistribution. There is a vast literature on the accommodation of sub-state nationalism which revolves around the idea that a regime of multinational federalism can defuse tensions between ethnonational groups sharing a state and offer fair terms of cooperation to minority nations. Multinational federations are political systems which grant a capacity of self-government to internal nations 1) by drawing boundaries so that national minorities can form a majority within one or more federal subunits, thus enabling them to make democratic collective decisions without being outvoted by the national majority; and 2) by dividing the powers so that a 'nationality-based subunit' can have exclusive or shared jurisdiction over crucial areas such as culture, language, immigration, education and so on. We might add that a truly multinational federation formally recognizes its national minorities as such in the constitution and treat all its internal nations as equal partners (see for instance, Gagnon and Tully, 2001; Kymlicka 2001, 2007, Requejo 2004; Norman 2006; Pinder 2007; Gagnon 2010; De Schutter 2011, Seymour et Laforest 2011; Patten 2014; Grégoire and Jewkes 2015, Mathieu 2017, Guenette et Mathieu 2018). One may assert that such a system of multinational or plurinational federalism is fair because it provides roughly equal chances for majority and minority nations to promote their national identity (Norman 2006), because it protects minorities from aggressive nation-building assimilationist pressures from the majority nation that tend to dominate the central state (Kymlicka 2001), and because it provides equal recognition to both the majority and the minority nations (Patten 2014).

This way of understanding the accommodation of minority nations through the adoption of a plurinational federal system seems rather silent with regards to matters of redistribution. How should we conceive the link between equal recognition in plurinational states and the structure of the welfare state? One way to think about the relation between minority nationalism and the welfare state is to assert their independence from one another. One may argue that even if we accept that minority nations should be recognized and accommodated through federal mechanisms of shared rule and self-rule, recognition and autonomy for minority nations should be strictly limited to the realm of culture and identity. Belgium, in this regard, seems to embody such a model of multinational federalism in which decentralization in cultural matters (language, education, immigration) coexists with a centralized welfare state (Loobuyck and Sinardet 2017). As I explain in the last section, one may invoke powerful egalitarian objections to the idea that minority nations should enjoy fiscal autonomy inside a fiscally decentralized federation. From this perspective, minority nations may be recognized symbolically by state institutions, they may benefit from strong linguistic 'promotion rights' ${ }^{3}$, they may receive funding to establish cultural institutions promoting their literature, theater, film industry and the like, they may

\footnotetext{
${ }^{3}$ Linguistic rights include toleration rights, accommodation rights and promotion rights (Kymlicka and Patten 2003). The first kind of linguistic rights enables linguistic minorities to speak their own language in the private sphere. The second kind protects linguistic minorities from being excluded from the public sphere while they are in the process of learning an official or public language (for instance, by benefiting from translation and interpretation services in courts, hospitals, and in their relations without police forces). Promotion rights are stronger and grant linguistic minorities the power to use public institutions to encourage the use of their language, for instance by establishing an official language for public administration and public schools.
} 
also benefit from the political capacity to self-government in the realm of culture and identity by having their own legislatures with (shared or exclusive) jurisdiction over key areas of policy: language, telecommunication, education, cultural development; but, the structure of the welfare state should be left untouched. Redistributive functions should be in the hands of the central government. In other words, this perspective asserts that minority nations should be accommodated through a federal division of powers in which cultural issues are state or provincial competences. They must be able to control the school curriculum, make decisions regarding linguistic matters and choose how to promote their national symbols. Nonetheless, this view also asserts that fiscal matters and social policy should fall completely within the jurisdiction of the federal government. This view calls for cultural autonomy within a centralized welfare state; it grants minority nations the power to define and shape their identity but leaves the powers to raise revenues and spend on social programs in the hands of a central government. ${ }^{4}$

This cultural autonomy standpoint seems to be influent among some of the main liberal multiculturalist proponents of multinational federalism such as Kymlicka, Patten and Norman. It is not so much that these authors explicitly reject fiscal decentralization. Rather, the topic of fiscal decentralization is more or less absent or marginal in their work, which is more focused on topics such as language rights, control over the school curriculum, the importance of making collective decision with people sharing a common culture, symbolic constitutional recognition of minority nation and the right to secession (Kymlicka 1995, 2001, 2007; Gagnon and Tully 2001; Norman 2006; De Schutter 2011; Patten 2014). When applying his liberal theory of minority rights to the accommodation of minority nationalism within plurinational states, Kymlicka identifies "the following six policies as emblematic of the multicultural approach to sub-state national groups: (1) federal or quasi-federal territorial autonomy; (2) official language status, either in the region or nationally; (3) guarantees of representation in the central government or on constitutional courts; (4) public funding of minority language universities/schools/media; (5) constitutional or parliamentary affirmation of 'multinationalism'; (6) according international personality [to sub-state national groups]" (Kymlicka 2008, 71). Kymlicka claims that minority nations can legitimately engage into their own process of nation-building, a process of "promoting a common language and a sense of common membership in, and equal access to, the social institutions based on that language" (Kymlicka 2001, 27), so as to compete to and resist the nation-building efforts of central government dominated by a majority nation. To engage into such nation-building process, minority nations, according to him, use the same building tools as majority nation: "control over the language and curriculum of schooling, the language of government employment, the requirements of immigration and naturalization, and the drawing of internal boundaries" (Kymlicka 2001, 28). Fiscal decentralization, or the capacity for sub-state units to collect their own revenues (at least in part) and to engage into autonomous social spending, is not explicitly identified among the key elements of the liberal multiculturalist approach to minority nationalism. ${ }^{5}$

Allan Patten also seems to embrace the cultural autonomy only view. His approach based on equal recognition asserts that in a plurinational state, institutions must be designed to provide equal

\footnotetext{
${ }^{4}$ Elsewhere, I called this view "the unitary option" (Boucher and Maclure 2015) and discussed some objections to it.

${ }^{5}$ Kymlicka does discuss Indigenous self-government in connection with distributive justice (2001, 133-151) and identify social policy as a tool of nation-building in more recent works (see Banting and Kymlicka 2017). However, it is not explicitly included in the apparatus of self-government rights granted to minority nations and incorporated into earlier and more comprehensive statement of his theory of multinational federalism.
} 
recognition to majority national identity and to sub-state national identities. In his view, recognition is "a customized form of accommodation of an identity-related component of a conception of the good" (2014, p. 158). When a plurinational state adopts a unitary structure and retains all legislative powers at the level of the central government, it only accommodates (or facilitates) the expression of the identity-related preferences of members of the national majority. This violates the requirement of equal recognition. To provide equal recognition to members of sub-state nations, it is necessary for a plurinational state to adopt a federal-like structure or devolve powers to sub-state units so as to make sure that "significant functions and responsibilities are assigned to each level" $(2014,248)$. It is not clear, however, whether fiscal responsibilities are significant enough for fiscal decentralization to be required by equal recognition and if they are, it is not explained how fiscal responsibilities are connected to national identity. Some of his conclusions suggest that they are perhaps not so central to national identity and recognition. Indeed, Patten asserts that the 1999 Scottish devolution of powers from London to Edinburgh meets the requirement of equal recognition. Within the UK, it equally recognizes those who identify themselves as Scottish and those who view themselves as British and within Scotland it also provides equal recognition for those who identify as British $(2014,248)$. Yet, the Scottish devolution, although it granted important legislative powers to Scotland, did not include a strong level of fiscal decentralization, as it left Westminster responsible for collecting revenues before allocating it to sub-state units through a system of intergovernmental grants. The lack of fiscal autonomy provided by the 1999 devolution was criticized in the months prior to the 2014 Scottish referendum for independence by the proponents of both the devo-max and the devo-plus option, which all claimed more fiscal powers for Scotland, and by latter proponents of secession.

Following Kymlicka, Wayne Norman asserts that the constitution of a multinational state must have a federal character and must enable national minorities to engage into their own project of nationbuilding so as to resist the assimilationist pressures carried by the nation-building project of the majority nation (2006). Norman's approach centers on the means of nation-building at the disposal of central and federated states. Yet, fiscal tools do not figure in the contents of his nation-building toolbox, which lists official language policy, immigration and naturalization, the school curriculum, mandatory military service, mythologizing patriotic wars, promoting national symbols and holidays, the naming of streets, buildings, cities and geographical features, controlling national media and promoting sports in international competition (Norman 2006, 46-47). Norman nonetheless includes certain social policies as means of nation-building when providing concrete examples of successful nation-building strategies. He thus cites Quebec's nationalization of hydroelectricity and the Canadian healthcare system as important components of both Quebec and Canada's national identity. ${ }^{6}$

At this point, I need to highlight an important caveat about what the cultural autonomy only view is not. My claim is not that the proponents of this position endorse an ethics of cultural preservation. Some commentators criticize the liberal multiculturalist view on multinational federalism for being exclusively concerned with preserving the authenticity and distinctiveness of the traditional character of the culture of national minorities (Murphy 2001; Harty and Murphy 2005, 5-6, 10-13; Woons 2014, 97-98). However, this argument misses its target as liberal multiculturalists do not embrace such a preservationist ethic. For instance, Kymlicka makes it clear that self-government

\footnotetext{
${ }^{6}$ Norman also mentions that in a truly federal regime, taxing powers are among the powers that need to be on the list of the powers to be shared by both orders of government $(2006,107)$. Yet he does not specify how these powers need to be shared and why they matter for the fair allocation of the tools of nation-building between majority and minority nations.
} 
rights for national minorities aim at protecting them from assimilationist nation-building policies from the central state, they are protections against the power of national majorities which empowers them to pursue their own nation-building project (Kymlicka 1995, 35-44; 2001, 1-3, 28-29, ). This is fully compatible with allowing national minorities to use their nation-building capacity to promote (or not interfere with) internal cultural transformations. To be sure, Kymlicka welcomes the liberalization and modernization of Quebec society in the 1960s. For him, this process of cultural self-transformation did not weaken Quebec's claims to self-government on the ground that it undermined its cultural distinctiveness and authenticity, it rather increased the legitimacy of such claims (2001, 242-264). If proponents of the cultural autonomy view do not embrace the ethic of cultural preservation, they nonetheless centre their analysis on the connection between nationalism and culture and neglect the connection between nationalism and political economy.

In general, proponents of multinational federalism have not given a lot of importance to fiscal tools in the accommodation of minority nationalism. They have largely addressed multinational federalism in the language of recognition, leaving aside concerns related to redistribution. ${ }^{7}$ Of course, some of the policies they recommend for plurinational polities involve social spending, as is the case with public education in minority language. However, not much attention has been given to the fiscal implications of accommodating national minorities. It is one thing to say that public education should be provided in the language of a national minority. It is quite another to determine how public education should be funded. Should public education in minority language be funded directly by the central government? Via intergovernmental transfers? Or through taxes raised directly by the autonomous regional government of a national minority? Who should decide how much is spent on identity-sensitive social programs? Certain critics of majority nationalism have nonetheless provided a clearer picture of the role of fiscal tools in the expressions of unaccommodating forms of majority nationalism. For instance, Gagnon and Iacovino objected to the 1999 Social Union Framework Agreement, which increased the role of the Canadian federal government in social policy and social spending (Gagnon and Iacovino 2007, 49; Gagnon 2008 159-161). Those critics also target the spending power of the Canadian federal government, which is defined as "the power of [the federal] parliament to make payments to people or institutions or governments for purposes on which it (the parliament) does not necessarily have the power to legislate." 8 They remark that what is viewed by Anglophone Canadians as a positive tool of nation-building that helps build a more just Canadian society, is seen by many Quebecers as a 'nation-destroying' device that hampers its autonomy and negates the view that Quebec society is a distinct political community (Telford 2003, also see Gagnon and Iacovino 2007; Noël 2008, 2020).

\section{Equal Recognition Entails Fiscal Autonomy}

\footnotetext{
${ }^{7}$ For other defenses of multinational federations embracing the cultural autonomy only view, see Requejo 2004, 2012; De Schutter 2011. Some proponents of multinational federalism have nonetheless defended fiscal autonomy more explicitly: see Harty and Murphy 2005; Seymour and Gagnon 2012, Gagnon 2014, Mathieu 2017, Guénette and Mathieu 2018). As mentioned above, Béland and Lecours have established a strong connection between minority nationalism and social policy (Béland and Lecours 2006).

${ }^{8}$ Trudeau, Pierre Elliott (1969), Federal-Provincial Grants and the Spending Power of Parliament, Government of Canada, 4, quoted in Telford, 2003, 25.
} 
In the previous section, I described a standpoint that can be called the cultural-autonomy-only view. In this section, I challenge this view by claiming that cultural autonomy entails fiscal autonomy. Fiscal autonomy refers to a sub-state government's capacity to engage in public spending and to raise its own revenues. It encompasses both spending responsibilities and tax autonomy (Saunders 2018; Blöchiger and King 2006; Blöchiger and Rabesona 2009; Blöchiger and Nettley 2015). Fiscal decentralization obtains when sub-central governments enjoy some degree of fiscal autonomy. Fiscal decentralization and fiscal autonomy are a matter of degree in two different senses. On one hand, fiscal autonomy can be incomplete when sub-state governments have significant spending responsibilities but must mostly rely on intergovernmental transfers from the central government to access resources, as was the case in Scotland at the time of devolution in 1998-1999 (Rioux 2018). Fiscal autonomy is complete when, in addition to having meaningful spending responsibilities, sub-state governments can also raise their own revenues, as is the case with Quebec. On the other hand, fiscal autonomy can be weak when a sub-state government only accounts for a small fraction of total social spending and of the total taxes collected on its territory. It can be strong when sub-state governments retain nearly all spending responsibilities and taxation powers, as is the case with Navarre, the Basque Country and South Tyrol. ${ }^{9}$ The strength of fiscal autonomy is moderate when both layers of government have roughly equal fiscal responsibilities in terms of spending and taxing, as is the case in Canada (see Blöchiger and Rabesona 2009). In this section, I sketch an argument supporting the view that cultural autonomy and equal recognition in multinational federations require at least complete fiscal autonomy. In the next section, I will add that fiscal autonomy in plurinational federations should be moderate, in addition to being complete, so as to be compatible with the demands of equality.

One may argue that fiscal decentralization enables people to lead more autonomous lives and that it actually strengthens liberal values. The argument would run as follows: as the citizens of a federation enjoy mobility and freedom of movement across the boundaries of federated units, fiscal decentralization enables them to live in jurisdictions that enact diverse packages of social policies reflecting the values and preferences of their resident (who can choose to live in a different federated state if they do not agree with the social policies of the one they currently live in). However, as Levy points out (2007) this choice is not genuinely open for the members of multinational federations whose inhabitants face important linguistic and cultural barriers to their mobility. Although fiscal decentralization in plurinational state has less potential for improving individual choice than in merely territorial ones, it can nonetheless improve collective choice for national groups by granting sub-state national groups with greater over their resources and their spending decisions. The argument I present in this section is however different. In a nutshell, I defend the view that fiscal autonomy is a precondition of cultural autonomy and equal recognition. I provide two arguments supporting this view: first, to be able to make a valuable and significant use of their competences in the realm of culture, sub-state nations need some degree of fiscal autonomy; second, social policy is itself a tool of nation-building.

Firstly, cultural autonomy directly entails public spending. Nearly all the elements listed by proponents of the cultural-autonomy-only view involve public spending. Public education in an official language, support for cultural activities, establishing public media, developing a school curriculum,

\footnotetext{
${ }^{9}$ For a more detailed account of the varieties of institutional arrangements that can instantiate different levels of fiscal autonomy in fiscally decentralized states, see Blöchiger and King 2006, Blöchiger and Nettley 2015; Valdesalici and Palermo 2018.
} 
promoting national symbols and celebration are all activities that require regional governments to have access so significant financial resources and have the ability to make decisions with regard to how to spend them. If national minorities within plurinational states are to engage into their own nationbuilding project to counteract the tendencies of central states to project the identity of the majority nation, they must have the capacity to engage in public spending. There is no such thing as a purely symbolic, uncostly cultural autonomy detached from the fiscal functions of government. If the regional governments of sub-state nations are given certain powers in the realms of culture, language, and other identity shaping functions, they must have the capacity to spend as well as access to financial resources for those powers to be effective. In fact, to meaningfully exercise autonomy in any domain, sub-state governments need to have access to resources. As Anika Kress puts it: "Subnational revenue and expenditure powers are fundamental in determining the degree to which subnational entities can autonomously exercise their subnational competences. Without sufficient resources, subnational units would simply not be able to carry out their responsibilities nor to pursue policies that reflect their own priorities autonomously" (Kress 2018, 275, see also Wheare 1963; Gagnon and Seymour 2014, 4; Valdesalici 2018, 16; Noël 2020).

Secondly, the cultural-autonomy-only view cannot properly accommodate national minorities and provide the conditions for equal recognition because it does not acknowledge the complex relations between cultural autonomy, national identity and fiscal autonomy. As I previously highlighted, many political theorists, often labeled as 'liberal nationalists,' endorse the view that shared national identity is a precondition of redistribution and that the territorial scope of redistribution should match that of national identities. For liberal nationalists, a shared national identity produces the condition under which redistribution and the welfare state are possible. This view is puzzling for proponents of plurinational federalism who, as I explained, rest their case on the view that national identities overlap on single pieces of territory since the citizens of such plurinational polities have dual or nested national identities. In those polities, territorially bounded schemes of redistribution and territorially bounded fiscal regimes cannot simply match national identities as those are overlapping and are not encapsulated in exclusive territories. How then should redistribution and taxation be arranged in such overlapping political communities where national identities are juxtaposed on single pieces of territory? Before attending to this difficult puzzle, I want to stress that my argument entails that the relation between national identity and redistribution is not unidirectional and does not only go in the direction that liberal nationalist assume. What I would like to suggest is that social policy produces shared national identity. If this is correct, engaging in public spending, especially on important social programs, is an important way to exercise cultural autonomy. To put this differently, social spending is a tool of nation-building. Thus, holding social spending responsibilities firmly in the hands of central governments deprives national minorities from an important avenue to promote their identity. This represents an unfair allocation of the tools of nation building, which undermines equal recognition through a multinational federal system. Social policy can be a tool of nation-building in many ways.

Most obviously, social policy can express values of solidarity and social justice that can elicit the identification and command the loyalty of individuals. Many sub-state nationalist movements, such as Quebec and Scottish nationalisms, have offered more generous social programs than the central government in order to express their distinctive national character (Béland and Lecours 2006; McEwen 2006b; Johnson et al. 2017). This suggests that budgetary autonomy is required to enable national minorities to express and pursue their distinctive social preferences. Here, the values associated with 
social policy simply replace the standard markers of national identity such as culture, language and ethnicity. Although the capacity to pursue a distinctive social project is important for national minorities, this argument offers limited support for fiscal decentralization. Indeed, it seems to suggest that tax and budget autonomy are only relevant to the extent that national minorities have distinctive social preferences. Yet, national minorities have good reasons to seek fiscal decentralization even when their social preferences are not distinctive. It is only the content of social programmes and the values they express that plays a role in nation-building. Engaging in social spending and being the provider of social services is in itself a tool of nation-building. Drawing on the notion of social citizenship and on the integrative function of social policy, Harty and Murphy claim, in relation to Scottish nationalism, that: "[e]ven if the objectives of these [Scottish social programmes] are largely consistent with similar programmes in England and Wales, the fact that they are designed for and delivered exclusively to the Scottish people challenges the integrative function normally performed by state social programmes" (Harty and Murphy 2005, 45). Social policy does not only directly project certain identity markers (i.e. social preferences), as does enacting official language policies and promoting national symbols. It can further a national identity in a much more indirect, although no less efficient, way. For instance, the direct aim of healthcare policy is undoubtedly to promote public health and a fair access to healthcare. Yet, providing subsidized healthcare to a population might nonetheless, in addition to this, promote a sense of national identity more indirectly, by contributing, as a side effect, to shaping a sense of belonging to a shared community of solidarity. When an order of government provides services, it becomes more visible to its citizens, who become, in turn, more aware of its role in their lives and of their connection to this government. This is why sub-state nationalist governments often try to outstrip the visibility of state governments in the delivery of social programmes (Harty and Murphy 2005, 45).

Who provides a social service, the federal or the provincial/state government, has a profound impact on citizens' representation of the political communities to which they belong. By pooling the fiscal resources of a group together for the purpose of redistribution, a government, central or subcentral, can create and maintain a sense of common fate, of being subjected to the same economic insecurities and of fighting those together, as one team. Moreover, when a government provides a social service or a welfare benefit, it establishes itself as a relevant actor in the lives the recipients of those services and benefits and creates a direct bond between the individual and itself. This contributes in creating an identity reference point and turns the political community into something concrete, something that has a concrete impact in the lives of individuals, something that is not merely symbolic and folkloric. As Béland and Lecours summarize those two points (the direct link between the individual and the state, the representation of a meaningful community): "social policy not only generates a formal community of contributors and recipients, frequently conceptualized in national terms, but it also makes subjective connections between the nation and certain sets of values" (Béland and Lecours 2006, 21). Similarly, where and among whom social spending decisions are debated has a deep impact on the representation of the nation as a meaningful and concrete collective agent. Partaking in collective decision-making on social policy with one cultural group rather than another shapes the sense that this group is a full political community not just a collection of individuals sharing a folklore, a language and some traditions. This is why Gagnon and Iacovino voice concerns that the 1999 Social Union Framework Agreement amounts to an expression of a pan-Canadian majority nationalism, which has the effect of entrenching the vision that Canada is a single mononational political community (Gagnon and Iacovino 2007, 45; Gagnon 2014). 
So far, I only established that in order to equally recognize the national identities of minority nations within plurinational states, the federated governments of these minority nations need to have access to financial resources and to be able to spend on social programs and on various policies promoting their culture and identity. This still does not establish that multinational federations, to equally recognize national minorities, must grant complete fiscal autonomy to their minority nations. I have only so far provided an argument for what I called earlier in this section weak fiscal autonomy (a capacity to spend which depends on intergovernmental top down vertical transfers). To climb the next step in the argument and reach the conclusion that cultural autonomy entails complete fiscal decentralization, one needs to make a stronger connection between sub-state autonomy (in cultural and social matters) and tax autonomy. The notion of a secure and stable access to resources is key to understanding this connection.

To be genuinely able to enact social policies and policies directly promoting its culture and identity, the government of a national minority needs a secure access to financial resources. To have such a secure access, this government needs to be able to collect its own revenues so as to be able to adjust its revenues autonomously in accordance to its spending decisions. Depending on transfers of resources from other orders of governments, from the federal level, cannot provide a secure and stable access to financial resources, especially when these other orders of government are largely dominated by a majority nation hostile or insensitive to the aspirations of the national minority. A minority nation could not rely on the benevolence of a central government dominated by a majority nation desiring to limit and stifle expressions of attachment to that minority nation (Guénette and Mathieu, 2018). Moreover, top down intergovernmental transfers can be tied to conditions that reflect the choices and priorities of the majority nation and limit the legislative autonomy of sub-state governments that are supposed to give expression to the democratic choices of national minorities. Even when intergovernmental transfers are unconditional and come with no strings attached, their total amount can be adjusted by the central government in ways that do not reflect the eventual policy preference of a national minority for more social spending. Those arguments against the reliance on top down vertical intergovernmental transfers depend on specific empirical circumstances such as the level of trust and animosity between rival national groups and differences between the policy preferences of such groups. However, those circumstances often characterize the state of relations between national groups in contemporary plurinational states. For instance, the connection between political autonomy and fiscal autonomy has been, in recent years, at the core of claims for more fiscal powers made by Scotland, before and after the 2014 referendum, for instance, who has to rely on transfers of resources collected by Westminster, despite its preference for a more generous welfare state, as its capacity to collect revenue autonomously only represents a small fraction of its total budget (Scottish Government 2013, 2014; McEwen and Petersohn 2015).

In this section, I argued that cultural autonomy and equal recognition entail a genuine capacity to engage into public spending and such capacity entail a certain degree of fiscal autonomy. In other words, complete fiscal decentralization is a precondition of equal recognition. The argument that I presented has three steps. First, I argued that in order to exercise meaningful autonomy in key areas related to cultural accommodation, minority nations must enjoy tax and spending autonomy. Second, I claimed that the capacity to engage in spending in areas of social policy not usually understood to be central to cultural accommodation is in fact an important tool of nation-building that should not be fully centralized in order to provide equal recognition to minority nations. Third, I maintained that the 
revenues of the federated units representing the identity of minority nations must, at least in part, be secured independently and not through transfers from the federal government.

One may wonder to which extent this argument is of special importance in plurinational federations. Indeed, theorists of federalism have already highlighted the importance of tax and spending autonomy for federated subunits whether or not those subunits were designed to give recognition to the distinct identities of minority nations. Echoing the works of Kenneth $\mathrm{C}$. Wheare (1963), Alain Noël explains that "to be autonomous, a federated entity must dispose of its own revenues, and be able to exercise its own jurisdiction without requiring transfers from the federal government, transfers that are always susceptible to be accompanied with conditions" (2009, 274-275). The principle of autonomy, at the heart of all federations, plurinational or not, entails that federated units must be able to secure revenues that matches their responsibilities relative to their constitutionally protected areas of jurisdiction. Moreover, such revenues should not depend on federal transfers. In other words, the first and third steps of the argument against the cultural-autonomy-only standpoint rest on premises that have been established since long by theorists of federalism that did not specifically focus on the importance of autonomy for minority nations.

Thus, theorists promoting the cultural-autonomy-only view have appealed to the normative ideal of federalism, but they ignored an important aspect of theories of federalism, namely, that autonomy always necessitates a capacity to generate revenues independently. Although not unique to the autonomy of federated units in plurinational federations, this feature of federal autonomy acquires a special importance in plurinational federations characterized by a clash between rival processes of nation-building (from the majority and minority nations). In such plurinational contexts, political forces moved by majority nationalism can be tempted to pay lip service to the ideal of autonomy by claiming that enough is already being done to accommodate minority nations by symbolically recognizing them and by granting them jurisdictions in key cultural areas without giving much thought to fiscal arrangements. In addition to this, the second step of the argument developed in this section highlights the connection between public spending, especially social spending, and nation-building. An order of government enjoying a monopoly over social spending benefits from a great capacity to shape the political identities of citizens, as compared to one limited to deciding the colour of its flag and the language spoken in public schools. Paying attention to this dimension of nationalism further highlights the special importance of tax and spending autonomy for minority nations in plurinational federations. In the next section, I turn to some of the most important objections raised against fiscal autonomy in federations, some of which specifically targeting fiscal autonomy within plurinational federations.

Before turning to this objection, I want to stress that my argument for fiscal decentralization is not incompatible with the arguments of liberal multiculturalist proponents of multinational federalism who have tended to embrace the cultural-autonomy view. Quite to the contrary, although some of them explicitly reject fiscal decentralization (see De Schutter, in this volume), most of them do not reject tax and budget autonomy, they simply do not give it a role as central as I argue it should be. I attempted to show that their view actually entails tax and budgetary autonomy for national minorities. Kymlicka, for instance, maintains that national minorities should have the same tools of nation-building than national majorities $(2001,28)$. My goal here was to expand this argument by arguing that since tax and spending responsibilities are tools of nation-building, they should be shared by national minorities and 
majorities. In the next section I explain why federal government should retain some taxation and social spending responsibilities).

\section{Distributive Equality and Fiscal Decentralization}

Egalitarian liberals are usually suspicious with regard to group autonomy and decentralization and they have plausible reasons to be specifically concerned with fiscal autonomy and fiscal decentralization in plurinational states. There are at least five ways in which fiscal decentralization in such states may undermine redistribution and equality. First, decentralization opens the door for policy variations between different sub-state units. Subunits may adopt different economic, educational or welfare policies leading to important variations between the opportunities and social services across the federation (Follesdal 2001, Segall 2007). Second, fiscal decentralization, or the devolution of responsibilities to raise revenues through taxation, leaves smaller, poorer or less industrialized regions with lesser resources to finance social services (Van Parijs 2015). Third, when fiscal decentralization is demanded by national minorities as part of a policy of recognition, issues of redistribution and socioeconomic equality may be presented as secondary to identity politics. Since citizens and politicians have limited time and energy to dedicate to political issues, identity politics may crowd out redistribution in public debates and policy making (Gitlin 1995, Barry 2001, Lilla 2017; Fukuyama 2018). Fourth, when fiscal responsibilities are decentralized, there is a risk that sub-state units will engage into fiscal competition leading to a race to the bottom (Oates 1972; Wilson 1986). Fifth, one may object that decentralization in multinational federations is going to undermine the conditions that make large-scale redistribution across federated states possible. Political autonomy, fiscal autonomy and symbolic recognition in a plurinational federation reinforce the sense of difference and distinctiveness within sub-state national groups. It weakens statewide national identity and reinforces local, sub-state nationalist identities, thereby undermining pan-federal solidarity (Van Parijs 2015).

Perhaps these objections hold in the case of full fiscal autonomy, that is, in the case of federal regimes in which sub-state units enjoy complete and very strong fiscal autonomy (Boucher and Maclure 2015). In such strongly decentralized federal arrangements, almost all fiscal powers remain in the hands of sub-state units, leaving the central government too weak to promote a common identity and leaving the poorest subunits with lesser financial resources thereby forcing them to have a higher tax burden to provide similar services as other federated subunits. However, the same thing does not apply in federations where spending and taxing responsibilities are shared among the different layers of government. In such a system of moderate fiscal autonomy and partial decentralization, the federal government is able to collect revenues so as to provide certain social services directly to its citizens and to implement intergovernmental transfers aimed at mitigating the disparities between different sub-units. For instance, the federal government of Canada compensate the weak fiscal capacity of the smallest province (such as Prince-Edward Island, Nova Scotia and New Brunswick) through a combination of conditional transfers (such as the Canada Health Transfer and the Canada Social Transfer) granted to all provinces (on the condition that they be spent on specific social programs meeting federal standards) and of unconditional transfers (to be spent as the province sees fit) (for 
more on the Canadian equalization payment scheme, see Courchesne 2007, Boucher and Maclure 2015; Béland et al. 2017). ${ }^{10}$

Moreover, by partly funding social programs, by delivering some of them directly and by funding them through conditional transfers, the federal government can play an important role in making sure that a minimal threshold of social services is delivered in all sub-state units. In such a context, social policy variations will be introduced when a sub-state unit decides to do more than the federal minimum (for instance by introducing a new childcare program or implementing a generous scheme of universal basic income). One may even claim that enabling federated states to engage into social experiments, can lead to the diffusion of progressive social programs to the whole federation (as happened in Canada after Saskatchewan introduced universal healthcare in 1947) (McEwen 2006a). Thus, horizontal intergovernmental inequalities in levels of social spending in a moderately decentralized fiscal federation will not be the result of a race to the bottom and might even introduce a race to the top. There is, moreover, no evidence to be gathered from the largest database on fiscal decentralization that fiscal autonomy for sub-state governments introduces such a race to the bottom as fiscal harmonization is generally observed (Blöchliger and Pinero Campos 2011).

In addition to this, a moderately fiscally decentralized plurinational federation can maintain the conditions for interregional solidarity and federal unity in three ways. Provided that the federal government leaves some space for internal national minorities to put forth their own nation-building project, it can use the standard cultural tools of nation building discussed above as well as fiscal tools. It can both promote national symbols and engage in some social spending. In addition, the federal government of these states can promote unity and cultivate the attachment of less developed regions through federal transfers. Some commentators refer to such transfers as the 'glue that holds the country together' (see Ahmad and Brosio 2018, 172, referring to Australia and Béland and Lecours 2014 and Kress 2018, referring to Canada). In such a regime where two or more orders of government pursue their own competing nation-building project, citizens cultivate a sense of belonging to two juxtaposed political communities and nurture bounds of solidarity that match those two communities.

Finally, it is very unlikely that in a plurinational state the claims for recognition of internal nations will crowd out concerns for redistribution, for two reasons. The first should be obvious by now: as I explained, recognition of plurinational diversity entails redistributive politics since leaving minority nations a space to engage into social policy is part of what it means to properly recognize them and to grant them some level of cultural autonomy. Secondly, minority nations often mobilize

${ }^{10}$ There are two important normative questions regarding the egalitarian credentials of Canada's Equalization Payments. The first has to do with the provinces' responsibility for lavish social spending and economic inefficiency. Given that the provinces are significantly autonomous with regard to decisions that affect their social spending and their economic development, can we say that equalization payment subsidize provinces that spend irresponsibly and that fail to be efficient and to promote economic development? Jocelyn Maclure and I provided an answer to such criticism of the equalization scheme (2015). The second has to do with the metric used to determine the amount of equalization transfers. Provinces falling below the average fiscal capacity, that is the per capita revenue a province would receive in applying a fixed taxation level, receive equalization payments. However, compensating for lower fiscal capacity may not be enough because it only provides a compensation to the poorest provinces with a lower capacity to generate revenue with a given taxation level. It does nothing to compensate provinces that may have higher expenditure needs, that is, provinces for which it is more expensive to provide a given social program (one might think that a factor as morally arbitrary as geography can affect the cost of providing services, as when, say, a coastal region is more likely to be affected by flooding or hurricanes, or when Arctic regions have more difficulties growing food and greater transportation costs to import it). Some federations, like Australia, determine the amount of equalization transfers by looking at differentials in expenditure needs (Ahmad and Brosio 2018, 177-178). 
around social policy (see for instance Keating 1996; Béland and Lecours 2006 and McEwen 2006b; Banting and McEwen 2018). Nationalist parties often claim to have social policy preferences that are different from those of the central state. Several sub-state nationalist movements, in Quebec and Scotland for instance, have positioned themselves as more progressive than other parts of the state they belong to and have sought to secede precisely so as to be better able to pursue their left-of-centre agenda. For those nationalist movements, insisting on distinct social preferences and values is a good way to assert an inclusive, distinct national identity without and to avoid charges of ethnic nationalism. As Béland and Lecours summarize those two points: "nationalism is as much about solidarity as it is about language and culture".

\section{Conclusion}

In this paper, I have highlighted that nationalism, in general, and sub-state nationalism, more specifically, tend to be viewed as a purely cultural phenomenon by nationalism scholars. This has led normative political philosophers to understand the accommodation of sub-state nationalism in terms of purely cultural multinational federalism, thereby ignoring how sub-nationalists seek to reshape the modern welfare state. As Béland and Lecours have pointed out: "The resurgence of sub-state nationalism and the emergence of the modern welfare state are certainly among the most striking political developments of the second half of the twentieth century, but relatively little has been written to explore the possible interactions between the two" $(2006,1)$. I have argued that a proper normative theory of multinational federalism needs to take into account the connection between recognition and redistribution by arguing that equal recognition through federal arrangements designed to provide cultural autonomy to minority nations actually entails a degree of fiscal autonomy. I have also maintained that although full fiscal autonomy for sub-state governments raise some serious egalitarian concerns, a proper sharing of fiscal responsibilities between central and sub-state governments can alleviate the tensions between autonomy and distributive equality.

\section{References}

Anderson, Benedict (1993). Imagined Communities, London: Verso.

Ahmad, Ehtisham an Giorgio Brosio (2018), "Can Lessons from Equalisation Transfers in Industrial Countries be Applied to Reforms in Emerging-Market Countries?", in Alice Valdesalici and Francesco Palermo, Comparing Fiscal Federalism, Boston: Brill, 169-189.

Archibugi, Daniele, 2008, The Global Commonwealth of Citizens: Toward Cosmopolitan Democracy, Princeton: Princeton University Press.

Balcells, Laia, José Fernández-Albertos and Alexander Kuo (2015), 'Preferences for Inter-Regional Redistribution', Comparative Political Studies 48/10: 1318-1351.

Banting, Keith and Will Kymlicka (2017), "Introduction: The Political Sources of Solidarity in Diverse Societies" in Banting, Keith and Will Kymlicka, eds., The Strains of Commitment. The Political Sources of Solidarity in Diverse Societies, Oxford: Oxford University Press, 1-58.

Barriteau, Claude (1998), "Pour une conception civique du Québec", L'Action nationale, 86/7, pp. 105-168. 
Barry, Brian (2002), Culture and Equality: An Egalitarian Critique of Multiculturalism, Cambridge, MA: Harvard University Press.

Beitz, Charles (1979), Political Theory and International Relations, Princeton: Princeton University Press.

Béland, Daniel, André Lecours, Gregory P. Marchildon, Haizhen Mou and M. Rose Olfert (2017), Fiscal Federalism and Equalization Policy in Canada, Toronto: University of Toronto Press.

Béland, Daniel and André Lecours (2014), "Accommodation and the politics of fiscal equalization in multinational states: The case of Canada", Nations and Nationalism 20/2: 337-354.

Berghe, Peter van den (1981). The Ethnic Phenomenon, New York, Elsevier.

Blake, Michael (2002), "Distributive Justice, State Coercion, and Autonomy", Philosophy and Public Affairs, 30/3, 256-296.

Blöchliger, Hansjörg and José Pinero-Campos (2011), “Tax Competition Between Subsentral Governments”, OECD Working Papers on Fiscal Federalism, No. 13, Paris: OECD Library.

Boucher, François and Jocelyn Maclure (2015), "Federal Distributive Justice. Lessons from Canada," in Jean-François Grégoire and Michael Jewkes, Redistribution and Recognition in Multinational Federations, Leuven University Press, 157-182.

Brock, Gillian (2009), Global Justice: A Cosmopolitan Account, Oxford University Press.

Cabrera, Luis, 2004, Political Theory of Global Justice: A Cosmopolitan Case for the World State, New York: Routledge.

Caney, Simon (2005), Justice Beyond Borders: A Global Political Theory, Oxford: Oxford University Press.

Connor, Walker (1993), Ethnonationalism. The Quest for Understanding, Princeton: Princeton University Press.

Courchene, Thomas. J. (2007), “A Short History of Equalization,” Policy Options, March: 22-29.

De Schutter Helder (2011), "Federalism as Fairness," The Journal of Political Philosophy, 19 (2) $167-$ 189.

Føllesdal Andreas. (2001), "Federal Inequality Among Equals: A Contractualist Defense," Metaphilosophy, 32(1/2): 236-55.

Fukuyama, Francis (2018), Identity: The Demand for Dignity and the Politics of Resentment, New York: Farrar, Straus and Giroux.

Gagnon, Alain G. (2008), La raison du plus fort. Plaidoyer pour un fédéralisme multinational, Montréal : Québec Amérique.

Gagnon, Alain G., (2010), The Case for Multinational Federalism. Beyond the All-Encompassing Nation. New York: Routledge.

Gagnon, Alain G. (2014), Minority Nations in the Age of Uncertainty: New Paths to National Emancipation and Empowerment Toronto: University of Toronto Press. 
Gagnon A. G. and Iacovino R. (2007). Federalism, Citizenship and Quebec: Debating Multinationalism. Toronto: University of Toronto Press.

Gagnon, A. G. and James Tully. (2001). Multinational Democracies. Cambridge (MA): Cambridge University Press.

Geertz, Clifford (1973), The Interpretation of Culture, New York: Basic Book.

Gellner, Ernest (1983), Nations and Nationalism, New York, Cornell University Press.

Gilabert, Pablo (2012), From Global Poverty to Global Equality, Oxford University Press.

Gitlin, Todd (1995), The Twilight of Common Dreams: Why America Is Wracked by Culture Wars, New York: Henry Holt \& Co.

Grégoire, Jean-François and Michael Jewkes, eds. (2015), Recognition and Redistribution in Multinational Federations, Leuven: Leuven University Press.

Habermas, Jürgen (1998), The Inclusion of the Other. Studies in Political Theory, Edited by Ciaran Cronin and Pablo De Greiff, Cambridge: MIT Press.

Harty, Siobhán and Michael Murphy (2005), In Defence of Multinational Citizenship, Cardiff: University of Wales Press.

Heath, Joseph (2005), "Rawls on Global Justice: A Defense", in Daniel Weinstock (ed) Global Justice, Global Institutions. Canadian Journal of Philosophy, Supplementary, 31, 193-226.

Held, David et Anthony McGrew (2002), Governing Globalization: Power, Authority and Global Governance, Cambridge : Polity Press.

Held, David (1995), Democracy and the Global Order: From the Modern State to Cosmopolitan Governance, Malden, MA: Polity.

Hobsbawm, Eric J. (1990). Nations and Nationalism since 1780: Programme, Myth, Reality, Cambridge, Cambridge University Press.

Horowitz, Donald L. (1985), Ethnic Groups in Conflict, Berkeley, CA: University of California Press.

Johnston, Richard, Matthew Wright, Stuart Soroka, and Jack Citrin (2017), "Diversity and Solidarity: New Evidence from Canada and the US" in Banting, Keith and Will Kymlicka, eds., The Strains of Commitment. The Political Sources of Solidarity in Diverse Societies, Oxford: Oxford University Press, 152-176.

Keating, Michael (1996), Nations against the State: The New Politics of Nationalism in Quebec, Catalonia and Scotland, New York: St. Martin's Press.

Kymlicka, Will (1995), Multicultural Citizenship: A Liberal Theory of Minority Rights, Oxford: Oxford University Press.

Kymlicka, Will (2001), Politics in the Vernacular. Nationalism, Multiculturalism and Citizenship, Oxford: Oxford University Press.

Kymlicka, Will (2007), Multicultural Odysseys. Navigating the New International Politics of Diversity, Oxford University Press. 
Kymlicka, Will and Alan Patten (2003), "Language Rights in Political Theory: Context, Issues, and Approaches" in Kymlicka, Will and Alan Patten, eds., Language Rights and Political Theory, Oxford: Oxford University Press, 1-51.

Laborde, Cécile (2002), "From Constitutional to Civic Patriotism", British Journal of Political Science, 32, pp. 591-612.

Laborde, Cécile (2001), "The Culture(s) of the Republic. Nationalism and Multiculturalism in French Republican Thought", Political Theory, 29/5, pp. 716-735.

Levy, Jacob T. (2007), "Federalism and the Old and New Liberalisms", Social Philosophy and Policy, 24/1: 306-326.

Levy, Jacob T. (2015), Rationalism, Pluralism and Freedom, Oxford: Oxford University Press.

Lilla, Mark (2017), The Once and Future Liberal. After Identity Politics, New York: Harper.

Loobuyck, Patrick and Dave Sinardet (2017), "Belgium: A Hard Case for Liberal Nationalism?”, in Banting, Keith and Will Kymlicka, eds., The Strains of Commitment. The Political Sources of Solidarity in Diverse Societies, Oxford: Oxford University Press, 389-419.

Mathieu, Félix (2017), Le pluralisme à l'ère des sociétés complexes, Sainte-Foy: Presses de l’Université Laval.

Mathieu, Félix and Dave Guénette (2018), "Introducing a Societal Culture Index to Compare Minority Nations", Publius: The Journal of Federalism, 48/2: 217-243.

McEwen, Nicola and Bettina Petersohn (2015), "Between Autonomy and Interdependence: The Challenges of Shared Rule after the Scottish Referendum”, The Political Quarterly, 86/2: 192-200.

McEwen Nicola (2006a). "Does the recognition of national minorities undermine the welfare state?," In K. Banting and W. Kymlicka (eds.), Multiculturalism and the Welfare State. Recognition and Redistribution in Contemporary Democracies. Oxford: Oxford University Press.

McEwen, Nicola (2006b), Nationalism and the State. Welfare and Identity in Scotland and Quebec, Brussels: Peter Lang.

Mill, John Stuart (1997 [1862]), "Centralisation," in Collected works of John Stuart Mill, John Mercel Robson, ed., Vol 19. Toronto University Press.

Miller David. (1995), On Nationality, Oxford: Oxford University Press.

Miller, David (1998), "Secession and the Principle of Nationality", in Margaret Moore, National SelfDetermination and Secession, Oxford: Oxford University Press, 62-78.

Miller, David (2008), National Responsibility and Global Justice, Oxford: Oxford University Press.

Moore, Margaret (2001), The Ethics of Nationalism, Oxford: Oxford University Press.

Murphy, Michael (2001), "The Limits of Culture in the Politics of Self-Determination", Ethnicities, 1/3, 367-388.

Noël, Alain (2008), "Fédéralisme d'ouverture et pouvoir de dépenser", Revista d'Estudis Autonòmics i Federal, 7: 10-36. 
Noël, Alain (2009), "Balance and Imbalance in the Division of Financial Resources", in Alain G. Gagnon (ed.), Contemporary Canadian Federalism: Foundations, Traditions, Institutions, Toronto, University of Toronto Press, 273-302.

Noël, Alain (2020), "Le fédéralisme fiscal comme marqueur du fédéralisme”, in Félix Mathieu, Dave Guénette and Alain-G. Gagnon (eds.), Cinquante déclinaisons de fédéralisme: théories, enjeux et études de cas, Montréal : Presses de l’Université du Québec, 97-110.

Nagel, Thomas (2005), “The Problem of Global Justice”, Philosophy and Public Affairs, 33/2, 113147.

Norman, Wayne (2006), Negotiating Nationalism. Nation-Building, Federalism, and Secession in the Multinational State. Oxford: Oxford University Press.

Oates, Wallace (1972), Fiscal Federalism, Harcourt Brace Jovanovich.

Patten, Alan (2014), Equal Recognition: The Moral Foundations of Minority Rights, Princeton NJ: Princeton University Press.

Pinder, John (2007), "Multinational Federations: Introduction”, Michael Burgess and John Pinder, eds., in Multinational federations, New York: Routledge., , 1-16.

Rawls, John (1971), A Theory of Justice, Cambridge, MA: Harvard University Press.

Rawls, John (1999), The Law of Peoples, with "The Idea of Public Reason Revisted", Cambridge : Harvard University Press.

Requejo Ferran (2004). Multinational Federalism and Value Pluralism: The Spanish Case. London: Routledge.

Rioux, Hubert (2018), L'autonomie écossaise aujourd'hui, Centre d'analyse politique - Constitution et Fédéralisme, https://capcf1.wixsite.com/accueil/actualites/l-autonomie-\%C3\%A9cossaise-aujourd$\underline{\text { hui }}$

Rosenau, James N. et Ernst Otto Czempiel (dir.) (1992), Governance Without Government : Order and Change in World Politics, Cambridge: Cambridge University Press.

Sanjaume, Marc (2018), "Le débat catalan et l'éthique de la sécession", in Patrick Taillon and Amélie Binette (eds.), La démocratie référendaire dans les États plurinationaux, Québec, Presses de l’Université Laval.

Saunders, Cheryl (2018), "Financial Autonomy vs. Solidarity: A Dialogue between Two Complementary Opposites", in Alice Valdesalici and Francesco Palermo, Comparing Fiscal Federalism, Boston: Brill, 40-59.

Schmidt, Royal J. (1956), “Cultural Nationalism in Herder”, Journal of the History of Ideas, 17/3, 407417.

Scottish Government (2014), More Powers for the Scottish Parliament. Scottish Government Proposals, Edinburgh: The Scottish Government.

Scottish Government (2013), Scotland's Future: Your Guide to an Independent Scotland. Edinburg: Scottish Government.

Seymour, Michel, (1999), La nation en question, Montréal : l’Hexagone. 
Seymour Michel and Alain-G. Gagnon (2012), Multinational Federalism: Problems and Prospects. Cambridge: Cambridge University Press.

Seymour, Michel et Guy Laforest (2011), Le fédéralisme multinational : Un modèle viable?, Berne : Peter Lang.

Segall, Shlomi. (2007). "How devolution upsets distributive justice", Journal of Moral Philosophy, 4 (2): 257-272.

Shorten, Andrew (2015), "Federalism, Contractualism, and Equality", in in Jean-François Grégoire and Michael Jewkes, Recognition and Redistribution in Multinational Federations, Leuven: Leuven University Press, 135-156.

Singer, Peter (1972), "Famine, Affluence and Morality", Philosophy and Public Affairs, Vol. 1, No. 1, p. 229-243 (revised edition).

Smith, Anthony D. (1986). The Ethnic Origins of Nations, Cambridge, Blackwell Publishers.

Tamir, Yael (1993), Liberal Nationalism, Princeton University Press.

Tan, Kok. Chor (2004), Justice Without Borders: Cosmopolitanism, Nationalism and Patriotism. Cambridge : Cambridge University Press.

Taylor, Charles (1991), "Shared and Divergent Values", in Ronald Watts and Douglas M. Brown (ed.), Options for a New Canada, University of Toronto Press, 53-76.

Trudeau, Pierre Elliott (1969), Federal-Provincial Grants and the Spending Power of Parliament, Government of Canada, 4, quoted in Telford, 2003, 25.

Van Parijs Philippe (2004), "Just Health Care in a Pluri-national Country”, In Sudhir Anand, Fabienne. Peter and Amartya Sen (eds.), Public Health, Ethics, and Equity, Oxford: Oxford University Press, $163-180$

Van Parijs, Philippe (2015), "Fiscal Federalism and Solidarity: In Search of an Ideal Formula", in Jean-François Grégoire and Michael Jewkes, Recognition and Redistribution in Multinational Federations, Leuven: Leuven University Press, 183-192.

Valdesalici, Alice (2018), "Defining Fiscal Federalism", in Alice Valdesalici and Franceso Palermo, Comparing Fiscal Federalism, Boston: Brill, 11-21.

Valdesalici, Alice and Francesco Palermo (2018), Comparing Fiscal Federalism, Boston: Brill.

Watts, Ronald L. (1999), Comparing Federal Systems, McGill-Queen’s University Press.

Wheare, Kenneth C. (1963), Federal Government, $4^{\text {th }}$ ed., Oxford: Oxford University Press.

Wilson, John D. (1986), “A Theory of Interregional Tax Competition”, The Journal of Urban Economics, 19/3: 296-315.

Wilson, William A. (1973), "Herder, Folklore and Romantic Nationalism”, The journal of Popular Culture, 6 (Spring), 819-835.

Woons, Marc (2014), "Social Justice Beyond the Nation-State: Liberal Nationalism in Multinational Contexts", St Antony's International Review, 10/1: 82-109. 